\title{
Growth performance of three pejerrey genetic groups in intensive culture system
}

\section{Desempenho em crescimento de três grupos genéticos de peixe-rei criados em sistema intensivo}

\author{
Rafael Aldrighi Tavares ${ }^{1 *}$; João Morato Fernandes²; Verônica Hammes Garcia²; \\ Sérgio Renato Noguez Piedras ${ }^{3}$; Juvêncio Luis Osório Fernandes Pouey ${ }^{3}$; Nelson \\ José Laurino Dionello ${ }^{3}$; Heden Luiz Marques Moreira ${ }^{4}$
}

\begin{abstract}
This study examined the growth performance of Odontesthes bonariensis, O. humensis and hybrid (O. bonariensis $\mathrm{X} O$. humensis) in intensive culture system for a period of 180 days, using the body weight $(\mathrm{W})$, total length (Lt), condition factor (CF), allometric coefficient (b), specific growth rate (SGR) and estimates of body weight and maximum total length $\left(\mathrm{W}_{\max }, \mathrm{Lt}_{\max }\right)$ as indicators. Fish were randomly selected from three genetic groups (Bonariensis, Humensis and Hybrid), divided into water recirculation system consisting of 12 tanks $(50 \mathrm{~L}) .12$ measurements of body weight and total length $(0$, $2,7,14,21,30,45,60,75,90,120,180$ days) were taken by means of a random sample of 10 subjects per replicate. All genetic groups grew in weight and length over the period analyzed, being influenced by the genetics of each species. $O$. bonariensis showed the best performance in growth and hybrid fish showed intermediate growth and estimated maximum body weight exceeding the pure species. Based on these results, it would be helpful the selective breeding and formation of domesticated strains.
\end{abstract}

Key words: Odontesthes bonariensis, Odontesthes humensis, hybrid, Genetic improvement

\section{Resumo}

Este estudo analisou o desempenho em crescimento de Odontesthes bonariensis, O. humensis e do híbrido $O$. bonariensis e $O$. humensis em sistema de criação intensivo, por um período de 180 dias, utilizando como indicadores o peso corporal $(\mathrm{Pc})$, comprimento total $(\mathrm{Ct})$, fator de condição $(\mathrm{FC})$, coeficiente alométrico (b), taxa de crescimento específico (TCE) e estimativa de peso corporal e comprimento total máximo $\left(\mathrm{Pc}_{\max }, \mathrm{Ct}_{\max }\right)$. Os peixes foram selecionados aleatoriamente de três grupos genéticos (Bonariensis, Humensis e Híbrida), divididos em sistema de recirculação de água composto de 12 aquários de 50L. Foram realizadas 12 medidas de peso corporal e comprimento total $(0,2,7$, $14,21,30,45,60,75,90,120,180$ dias), por meio de uma amostragem aleatória de 10 indivíduos por repetição. Todos os grupos genéticos cresceram em peso corporal e comprimento total ao longo do período analisado, sendo influenciadas pela genética de cada espécie. $O$. bonariensis apresentou o melhor desempenho em crescimento e os peixes híbridos apresentaram um crescimento intermediário

\footnotetext{
${ }^{1}$ Prof. Dr. of Department of Animal Science and Biological Sciences, UFSM, Campus Palmeira das Missões, RS, Brasil. E-mail: rafaaldrighi@gmail.com

${ }^{2}$ Postgraduate Students in Animal Science, Department of Animal Science, Faculty of Agronomy Eliseu Maciel, UFPel, Pelotas, RS, Brasil. E-mail: moratofernandes@hotmail.com; veronica.hgarciia@gmail.com

${ }^{3}$ Profs. Drs. of Department of Animal Science, Faculty of Agronomy Eliseu Maciel, Universidade Federal de Pelotas UFPel, Pelotas, RS, Brasil. E-mail: sergiopiedras@hotmail.com; juvencio@ufpel.tche.br; dionello@ufpel.edu.br

${ }^{4}$ Prof. Dr. of Department of Zoology and Genetics, Institute of Biology, UFPel, Pelotas, RS, Brazil. E-mail: heden.luiz@gmail.com

* Author for correspondence
} 
e uma estimativa de peso corporal máximo que superou as espécies puras. Com base nestes resultados, seria útil a seleção de reprodutores e formação de linhagens domesticadas.

Palavras-chave: Odontesthes bonariensis, Odontesthes humensis, hídrido, melhoramento genético

\section{Introduction}

The cultivation of native fish species is being used extensively in aquaculture, but with no expression in the world market. The increased production is possible only by increasing the fish size or the growth of genetically improved fish (TAVE, 1996; GJEDREM, 2012; GJEDREM; ROBINSON; RYE, 2012). The domestication and genetic breeding of species used in aquaculture will be completed by controlling the biological aspects (NEWKIRK, 1980), including genetics and knowledge of the productive performance such as: weight, length, specific growth rate, condition factor and allometry coefficient. In the aquaculture, breeding programs are based on selective breeding, hybridization, triploidy and more currently the marker-assisted selection (GJEDREM, 1983; TAVE, 1996; HULATA, 2001; SACOBIE et al., 2012). The hybrid fish exhibit rapid growth and high disease resistance (SENANAN et al., 2004), also it stands out for its low cost and rapid achievement of genetically improved animals in comparison to selective breeding and marker-assisted selection.

The pejerrey is a representative of the order Atheriniform that includes fish found in fresh, marine, tropical and temperate waters (DYER, 2006). The genus Odontesthes has most of species and most widely distributed, being found in coastal marine waters, freshwater lakes (BEMVENUTI, 2006) and stored successfully in artificial basins of South American countries.

In Brazil, it is mainly present in the Mangueira and Mirim lagoons, located on the coast of Rio Grande do Sul, southern Brazil, where several species have been described as Odontesthes bonariensis, $O$. humensis, $O$. mirinensis, the species $O$. bonariensis and $O$. humensis being the most commonly found (PIEDRAS; POUEY, 2004; DYER, 2006).
The high quality of pejerrey, good commercial acceptance, meat taste, smell, texture and chemical characteristics similar to those of exquisite marine species (SOMOZA et al., 2008) have also encouraged the cultivation in places far from its native area of distribution such as Japan and Italy (BAIGÚN; COLAUTTI; GROSMAN, 2009).

The pejerrey production techniques progressively improved, being possible to complete the production cycle in rearing system in tanks (MIRANDA et al., 2006). In Japan there are several farms and intensive rearing of pejerrey (VELASCO; BERASAIN; OHASHI, 2008), but in countries like Brazil, Argentina, where this species is native, the production is still insufficient being restrict to production of fingerlings for resettlement and artisan culture (GROSMAN, 2002; PIEDRAS et al., 2009). In extensive farming in cages in shallow lakes of Argentina, the production of pejerrey reaches on average 2085 kilograms per hectare (COLAUTTI et al., 2010).

The starting point for successful rearing of pejerrey is the consolidation of a breeding program (TAVARES et al., 2011), requiring the identification of the animal model with best livestock performance. The present study aims at analyzing the growth performance of three pejerrey genetic groups $(O$. bonariensis, $O$. humensis and hybrid between $O$. bonariensis and $O$. humensis) in intensive rearing system.

\section{Material and Methods}

Breeders of $O$. bonariensis and $O$. humensis were collected in Mangueira Lake (S $322^{\circ} 59$ '12 "and W $52^{\circ} 42$ ' 42 ") and the crosses between 11 pairs of each species, forming the pure populations. For forming the hybrids were used 8 males of 
$O$. humensis and 8 females of $O$. bonariensis. Fertilized eggs were incubated separately in defined populations as: Bonariensis, Humensis and Hybrid, in funnel-type incubators, fiberglass with $200 \mathrm{~L}$ capacity at constant temperature of $20{ }^{\circ} \mathrm{C}$ for $11-12$ days.

The experiment was conducted at the Laboratory of Ichthyology at the Federal University of Pelotas. After hatching, 2000 larvae from each population were randomly selected and divided into four repetitions, totaling 6000 individuals. The animals were kept for 180 days in recirculating water system with tanks of 50 liters, being performed 12 measures in total length (Lt) and body weight (W) $(0,2,7,14$, $21,30,45,60,75,90,120,180$ days) by means of a random sample of 10 subjects per replicate.

From 0 to 90 days, the sampled animals were euthanized by deep anesthesia with benzocaine solution of $0.2 \mathrm{gL}^{-1}$ measured individually with ictiometer of $0.05 \mathrm{~mm}$ precision and weighed for each group of 10 animals, with $0.01 \mathrm{mg}$ precision scale. For the other analyzes, fish were fasted for 24 hours and then anesthetized with benzocaine solution of $0.1 \mathrm{gL}^{-1}$, measured and weighed individually. At 60, 90 and 120 days, the density by repetition was adjusted to 250,50 and 10 animals, respectively.

All fish were fed ad libitum on the same diet, where from 0 to 30 days the diet provided was zooplankton (rotifers, cladocerans and copepods), from 30 to 60 days diet was zooplankton (rotifers, cladocerans and copepods) and plus commercial feed, Acq line initial fingerlings-Supra ${ }^{\circledR}$ (Alisul, Brazil) with $56 \%$ crude protein and $3700 \mathrm{kcalkg}^{-1}$ of digestible energy, and from 60 to 180 days the animals were fed on the same commercial diet, 6 days per week, twice per day.

The animals were reared in a water recirculation system consisting of 12 water propylene tanks of $50 \mathrm{~L}$ and a biological filter of $500 \mathrm{~L}$, with mean temperature of $20.84 \pm 0.86^{\circ} \mathrm{C}, \mathrm{pH} 7.6 \pm 0.5,4.50 \pm 1.05$ $\mathrm{mgL}^{-1}$ dissolved oxygen, $0.002 \mathrm{mgL}^{-1}$ maximum ammonia total and for decreased stress and disease prevention was used a $5 \mathrm{gL}^{-1} \mathrm{NaCl}$, parameters considered acceptable for the species (PIEDRAS; POUEY, 2004). Siphoning was performed daily for the removal of waste accumulated at the bottom of tanks, including biometric days, and every 30 days cleaning of the biological filter.

Specific growth rate for body weight $\left(\mathrm{SGR}_{\mathrm{W}}\right)$ and specific growth rate for total length $\left(\mathrm{SGR}_{\mathrm{Lt}}\right)$ were calculated using the formulas proposed by Ricker (1979):

$$
\begin{aligned}
& \operatorname{SGR}_{\mathrm{w}}\left(\% \text { day }^{-1}\right)=\left(\left[\operatorname{Ln}\left(\mathrm{W}_{\mathrm{f}}\right)-\operatorname{Ln}\left(\mathrm{W}_{\mathrm{i}}\right)\right] / \mathrm{t}\right) \times 100 \\
& \operatorname{SGR}_{\mathrm{Lt}}\left(\% \text { day }^{-1}\right)=\left(\left[\operatorname{Ln}\left(\mathrm{Lt}_{\mathrm{f}}\right)-\operatorname{Ln}\left(\mathrm{Lt}_{\mathrm{i}}\right)\right] / \mathrm{t}\right) \times 100
\end{aligned}
$$

where $\mathrm{W}_{\mathrm{f}}$ e $\mathrm{W}_{\mathrm{i}}$ are body weight ( $\mathrm{mg}$ ) and $\mathrm{Lt}_{\mathrm{f}}$ and $\mathrm{Lt}_{\mathrm{i}}$ are total length $(\mathrm{mm})$ at the end and beginning of time period $t(d)$, respectively.

The alometric coefficient (b) was calculated by regression between $\mathrm{W}$ and $\mathrm{Lt}$, using the equation described by Richter et al. (2000):

$$
\mathrm{W}=\mathrm{aL} \mathrm{t}^{\mathrm{b}}
$$

Condition factor (CF) was calculated using the formula proposed by Bagenal (1978):

$$
\mathrm{CF}\left(\mathrm{mg} \mathrm{mm}^{-\mathrm{b}}\right)=\left(\mathrm{W} / \mathrm{Lt}^{\mathrm{b}}\right) \times 100
$$

where (b) is the coefficient of allometry.

Bartlett's test was used to test for data's variances homogeneity. The data on specific growth rate did not show normal distribution being transformed into logarithmic base. The variables total length, body weight and condition factor were analyzed using the ANOVA method, with populations (3 levels) and days (six levels) as fixed factors. Effects on specific growth rate for body weight and total length were examined by ANOVA, with population (3 levels) and time (5 levels) as fixed factors. When the ANOVA detected significant differences $(\alpha=$ 0.05 ), means were analyzed by multiple comparison test of Tukey.

The growth analysis for body weight and total length per day among populations was performed 
using linear regression. The estimate of the maximum length was obtained by linear regression equation of the total length and the estimated value of the maximum body weight was obtained by the equation:

$$
\mathrm{W}_{\max }=\mathrm{aLt}_{\max }{ }^{\mathrm{b}}
$$

where $\mathrm{Lt}_{\max }$ is the estimate of the maximum length.

All analyzes were performed with the aid of the software R 2.11.1.

\section{Results}

During the 180 days of growth, mortalities among populations showed no significant difference (mean 43\%).

All populations were grown in body weight and total length throughout the period analyzed (Figs 1, 2 and Table 1).

In the initial analysis (day 0) the three populations showed significant differences in mean body weight, whose the Humensis population was the one with the highest value and the Bonariensis with the lowest one. At 30 days all populations were similar in mean body weight and at 60 and 90 days the mean body weight was higher for populations Humensis and Bonariensis compared to the Hybrid one. The population Bonariensis had mean body weight higher than the other populations at 120 days and higher than Humensis at 180 days and similar to the Hybrid population. Although the population Humensis presented significantly higher initial body weight, at the end of the growing period had body weight $29.92 \%$ lesser than the Bonariensis population (Table 1). The initial average total length was significantly higher for Humensis population, but lower than Bonariensis at 60 days. The population Bonariensis continued with the average total length larger than the others, from day 60 until the end of 180 days, where $16.82 \%$ gain was obtained compared to the population Humensis and $10.03 \%$ compared to the Hybrid one (Table 1).

Initially, the mean for condition factor of Bonariensis population was lower than other populations, but at 30 days it was significantly higher. From day 60 until the end period, Bonariensis population remained with mean value higher than Humensis and similar to Hybrid. The mean condition factor shows a decreasing trend from 30 to 180 days for all populations (Table 1).

The specific growth rate for body weight tended to decrease throughout the period (Table 2). In the period between 0 and 30 days, the population Bonariensis has on average the specific growth rate for body weight significantly higher than the populations Humensis and Hybrid. During the periods 30-60, 60-90 and 120-180 days the specific growth rate for body weight was similar for the three populations (Table 2). The Hybrid population within 90 to 120 days had the highest average value of specific growth rate for body weight than the other populations, where the average body weight goes from a lower value at 90 days to a higher one at 120, compared to the Humensis population (Tables $1,2)$. 
Figure 1. Mean body weight (mg) between the three populations of pejerrey, over the period of 180 days of culture.

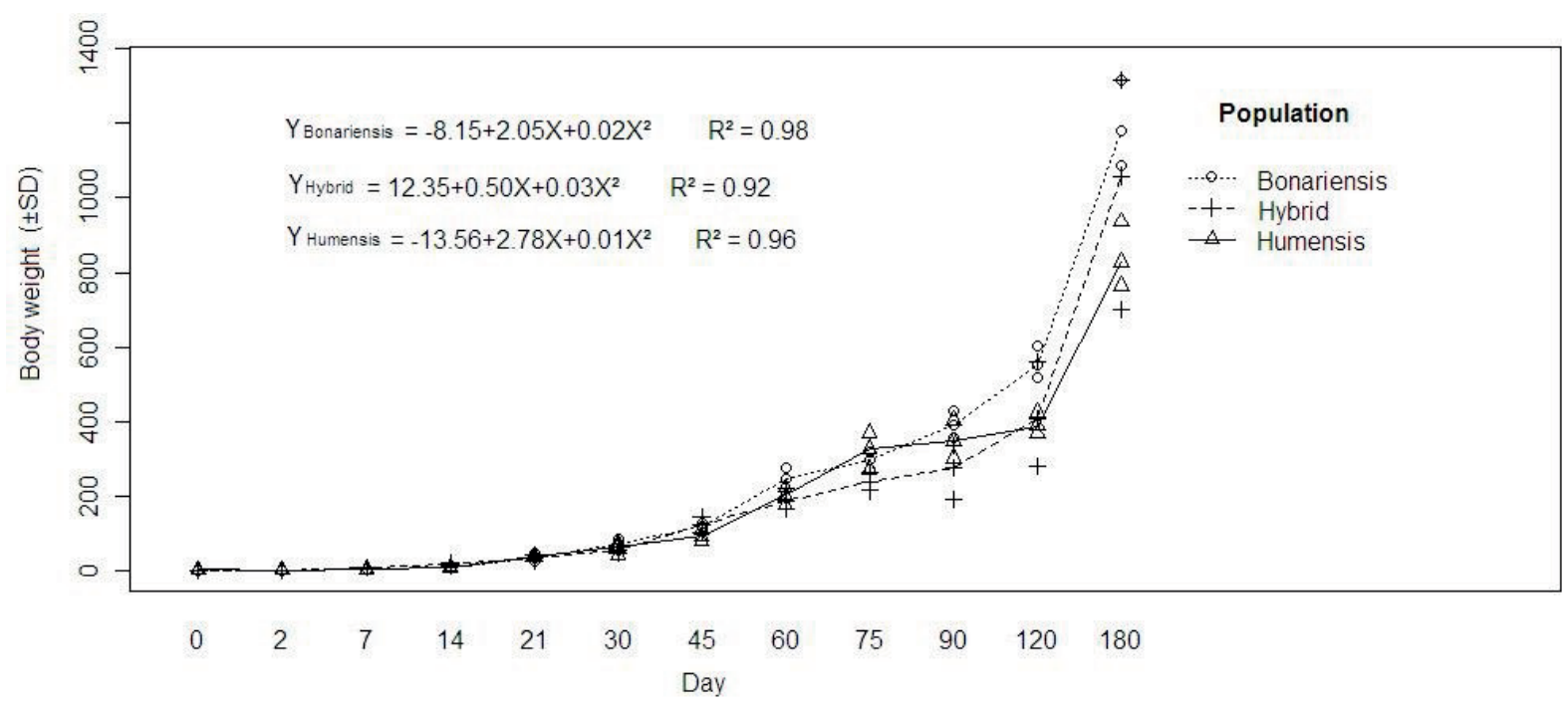

Source: Elaboration of the authors.

Figure 2. Mean total lenght $(\mathrm{mm})$ between the three populations of pejerrey over the period of 180 days of culture.

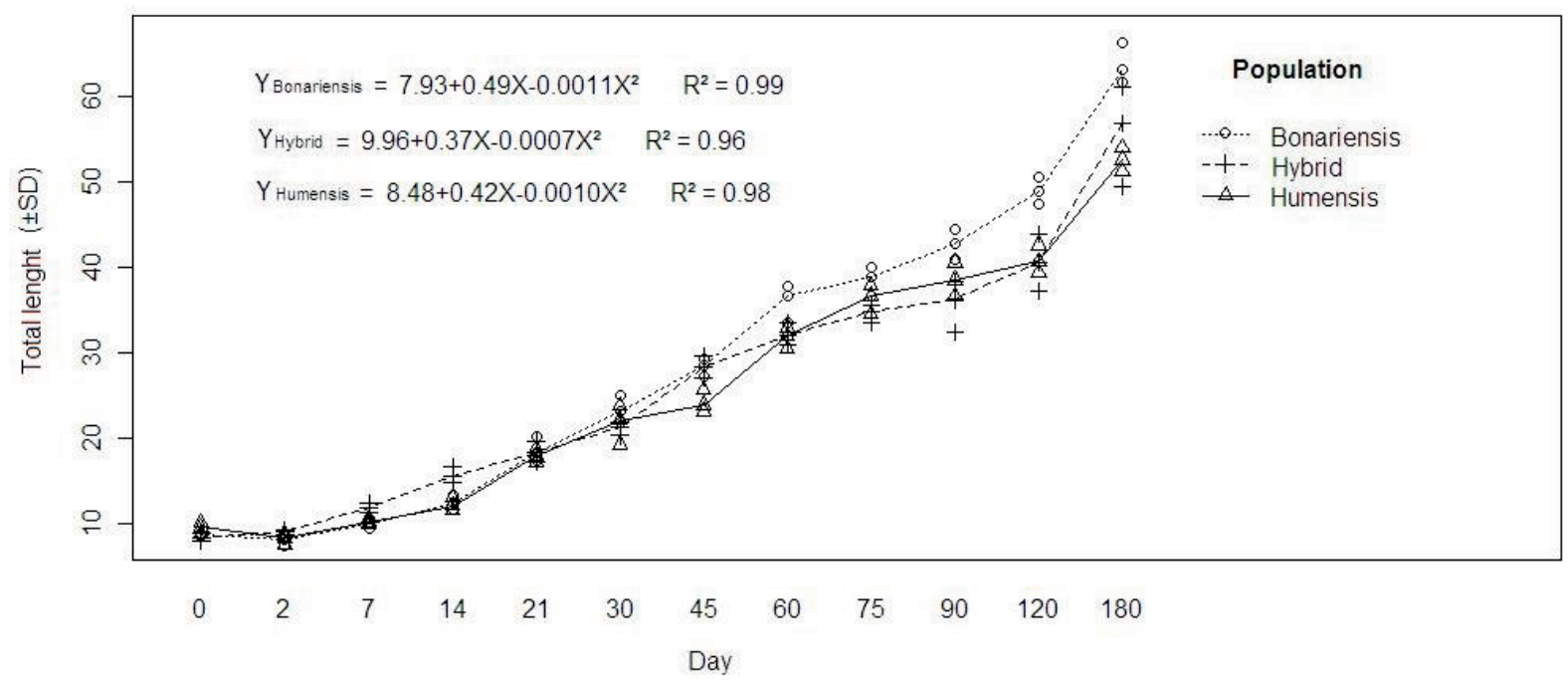

Source: Elaboration of the authors. 
Table 1. Mean $( \pm$ SD) body weight, total length and condition factor of three populations of pejerrey during the 180 days of culture.

\begin{tabular}{|c|c|c|c|c|c|c|}
\hline Population & Day 0 & Day 30 & Day 60 & Day 90 & Day 120 & Day 180 \\
\hline \multicolumn{7}{|c|}{ Body weight (mg) } \\
\hline Bonariensis & $1.3 \pm 0.01^{\mathrm{C}}$ & $71.6 \pm 12.6^{\mathrm{A}}$ & $247.5 \pm 30.2^{\mathrm{A}}$ & $391.2 \pm 31.3^{\mathrm{A}}$ & $489.2 \pm 14.2^{\mathrm{A}}$ & $1181.4 \pm 101.6^{\mathrm{A}}$ \\
\hline Hybrid & $2.5 \pm 0.09^{\mathrm{B}}$ & $57.07 \pm 6.4^{\mathrm{A}}$ & $185.5 \pm 23.4^{\mathrm{B}}$ & $274.9 \pm 67.6^{\mathrm{B}}$ & $446.2 \pm 8.1^{\text {в }}$ & $1058.9 \pm 280.4^{\mathrm{AB}}$ \\
\hline Humensis & $3.1 \pm 0.04^{\mathrm{A}}$ & $64.8 \pm 15.01^{\mathrm{A}}$ & $203.2 \pm 23.3^{\mathrm{A}}$ & $347.2 \pm 50.4^{\mathrm{A}}$ & $407.0 \pm 13.9^{\mathrm{C}}$ & $828.1 \pm 78.5^{\text {B }}$ \\
\hline \multicolumn{7}{|c|}{ Total length $(\mathrm{mm})$} \\
\hline Bonariensis & $8.8 \pm 0.2^{\mathrm{B}}$ & $23.2 \pm 1.4^{\mathrm{A}}$ & $36.6 \pm 2.1^{\mathrm{A}}$ & $42.7 \pm 1.5^{\mathrm{A}}$ & $48.9 \pm 1.4^{\mathrm{A}}$ & $63.1 \pm 2.1^{\mathrm{A}}$ \\
\hline Hybrid & $8.4 \pm 0.3^{\text {В }}$ & $21.40 \pm 0.7^{\mathrm{A}}$ & $32.1 \pm 1.1^{\mathrm{B}}$ & $36.2 \pm 2.6^{\mathrm{B}}$ & $40.5 \pm 2.8^{\text {в }}$ & $56.8 \pm 5.1^{\mathrm{B}}$ \\
\hline Humensis & $9.6 \pm 0.4^{\mathrm{A}}$ & $22.1 \pm 1.9^{\mathrm{A}}$ & $31.9 \pm 1.1^{\mathrm{B}}$ & $38.5 \pm 1.7^{\text {в }}$ & $40.7 \pm 1.3^{\mathrm{B}}$ & $52.5 \pm 1.1^{\mathrm{B}}$ \\
\hline \multicolumn{7}{|c|}{ Condition factor $\left(\mathrm{mg} \mathrm{mm}^{-b}\right)$} \\
\hline Bonariensis & $0.15 \pm 0.01^{\mathrm{B}}$ & $0.41 \pm 0.02^{\mathrm{A}}$ & $0.36 \pm 0.02^{\mathrm{A}}$ & $0.34 \pm 0.01^{\mathrm{A}}$ & $0.32 \pm 0.01^{\mathrm{A}}$ & $0.30 \pm 0.02^{\mathrm{A}}$ \\
\hline Hybrid & $0.26 \pm 0.03^{\mathrm{A}}$ & $0.28 \pm 0.01^{\mathrm{C}}$ & $0.24 \pm 0.01^{\mathrm{B}}$ & $0.24 \pm 0.01^{\mathrm{B}}$ & $0.25 \pm 0.02^{\text {в }}$ & $0.22 \pm 0.01^{\mathrm{B}}$ \\
\hline Humensis & $0.24 \pm 0.04^{\mathrm{A}}$ & $0.35 \pm 0.02^{\mathrm{B}}$ & $0.36 \pm 0.03^{\mathrm{A}}$ & $0.32+0.01^{\mathrm{A}}$ & $0.31 \pm 0.01^{\mathrm{A}}$ & $0.29 \pm 0.01^{\mathrm{A}}$ \\
\hline
\end{tabular}

Values with different upper case superscripts within a column o are significantly different at $\mathrm{p}<0.05$ (based on Tukey tests).

Source: Elaboration of the authors.

Bonariensis and Hybrid populations in the first period (0-30 days) differed from Humensis population for the mean values of specific growth rate for total length. In periods 30-60, 60-90, 90-120 no difference has occurred among populations and in the final period (120-180 days) the Hybrid population had higher specific growth rate for length compared to Humensis and Bonariensis populations (Table 2).

Table 2. Mean ( $\pm \mathrm{SD})$ specific growth rate for body weight $\left(\mathrm{SGR}_{\mathrm{W}}\right)$ and specific growth rate for total length $\left(\mathrm{SGR}_{\mathrm{Lt}}\right)$ of three populations of pejerrey during the 180 days of culture.

\begin{tabular}{lccccc}
\hline Population & Day 0-30 & Day 30-60 & Day 60-90 & Day 90-120 & Day 120-180 \\
\hline$S G R_{W}\left(\%\right.$ day $\left.^{-1}\right)$ & & & & \\
\hline Bonariensis & $13.30 \pm 0.57^{\mathrm{A}}$ & $4.14 \pm 0.87^{\mathrm{A}}$ & $1.55 \pm 0.50^{\mathrm{A}}$ & $0.75 \pm 0.19^{\mathrm{B}}$ & $1.46 \pm 0.14^{\mathrm{A}}$ \\
Hybrid & $10.39 \pm 0.34^{\mathrm{B}}$ & $3.93 \pm 0.41^{\mathrm{A}}$ & $1.25 \pm 1.19^{\mathrm{A}}$ & $1.69 \pm 0.91^{\mathrm{A}}$ & $1.39 \pm 0.49^{\mathrm{A}}$ \\
Humensis & $9.99 \pm 0.88^{\mathrm{B}}$ & $3.87 \pm 1.19^{\mathrm{A}}$ & $1.77 \pm 0.52^{\mathrm{A}}$ & $0.55 \pm 0.38^{\mathrm{B}}$ & $1.18 \pm 0.17^{\mathrm{A}}$ \\
\hline$S G R_{L t}\left(\%\right.$ day $\left.^{-1}\right)$ & & & & \\
\hline Bonariensis & $3.22 \pm 0.18^{\mathrm{A}}$ & $1.52 \pm 0.33^{\mathrm{A}}$ & $0.51 \pm 0.20^{\mathrm{A}}$ & $0.85 \pm 0.17^{\mathrm{A}}$ & $0.22 \pm 0.09^{\mathrm{B}}$ \\
Hybrid & $3.11 \pm 0.16^{\mathrm{A}}$ & $1.35 \pm 0.13^{\mathrm{A}}$ & $0.39 \pm 0.34^{\mathrm{A}}$ & $0.29 \pm 0.93^{\mathrm{A}}$ & $0.60 \pm 0.35^{\mathrm{A}}$ \\
Humensis & $2.75 \pm 0.19^{\mathrm{B}}$ & $1.24 \pm 0.39^{\mathrm{A}}$ & $0.62 \pm 0.18^{\mathrm{A}}$ & $0.02 \pm 0.09^{\mathrm{A}}$ & $0.50 \pm 0.11^{\mathrm{B}}$ \\
\hline
\end{tabular}

Values with different upper case superscripts within a column o are significantly different at $\mathrm{p}<0.05$ (based on Tukey tests).

Source: Elaboration of the authors.

The quadratic regression model fitted best for all populations, on both growth in body weight as in total length (Figures 1, 2).

The coefficient of allometry for the three populations was higher than three, ie, positive allometric growth with increase in total length more pronounced than in body weight for period of 180 days studied (Table 3).

The estimated maximum body weight was higher for the Hybrid population, but lower for the 
estimate of maximum total length. The population Bonariensis had estimated maximum total length higher than other populations, with estimated maximum body weight lower than the Hybrid population (Table 4).

Table 3. Allometry coefficient of three populations of pejerrey during the 180 days of culture.

\begin{tabular}{lcc}
\hline Population & Allometry coefficient & $\mathrm{R}^{2}$ \\
\hline Bonariensis & $0.0021 \mathrm{Lt}^{3.2394}$ & 0.98 \\
Hybrid & $0.0026 \mathrm{Lt}^{3.2259}$ & 0.99 \\
Humensis & $0.0027 \mathrm{Lt}^{3.2262}$ & 0.99 \\
\hline
\end{tabular}

Source: Elaboration of the authors.

Table 4. Estimated maximum body weight and maximum total length for the three populations of pejerrey.

\begin{tabular}{lcc}
\hline Population & $\begin{array}{c}\text { Maximum body } \\
\text { weight }(\mathrm{mg})\end{array}$ & $\begin{array}{c}\text { Maximum total } \\
\text { length }(\mathrm{mm})\end{array}$ \\
\hline Bonariensis & 1379.010 & 62.49 \\
Hybrid & 1391.185 & 53.47 \\
Humensis & 1015.296 & 59.67 \\
\hline
\end{tabular}

Source: Elaboration of the authors.

\section{Discussion}

The difference in growth performance among populations clearly demonstrates the genetic influences within each species and the diversification of pejerrey species supported by Dyer (2006) and Bemvenuti (2006). Body weight and initial total length for the three populations are similar to those found by Costa et al. (2009) for Odontesthes argentinensis. At 30 days the body weight and total length are similar to those reported by Piedras and Pouey (2004) for O. bonariensis fed on natural and artificial diets, and those found by Costa et al. (2009) for O argentinensis. Studies by Miranda et al. (2006) and Velasco, Berasain and Ohashi (2008) on intensive production of $O$. bonariensis had higher values of length and weight at 60 and 90 days compared to this study. Mean length and weight at 180 days showed superior performance of $O$. bonariensis compared to $O$. humensis. These means are similar to those obtained by Tsuzuki et al. (2000) studying the growth of Odontesthes hatcheri and $O$. bonariensis at 180 days and different saline concentrations. Colautti et al. (2010) in study of extensive farming in cages in the lake Lacombe, Argentina, during 315 days, obtained animals $O$. bonariensis with mean weight of $23.1 \mathrm{~g}$ and length $15.44 \mathrm{~cm}$.

Hybridization did not show the expected growth performance, ie, higher compared to pure species, unlike other hybrid fish that have rapid growth (SENANAN et al., 2004; PANG, 2005; GREEN; RAWLES, 2010), but studies involving hybrid fish are domesticated strains, used in breeding programs and related with sterility, and the pejerrey fish reach sexual maturation at least one year.

O. bonariensis showed better growth performance (W and Lt), even with lower total weight and initial total length. The fact that this species has high growth performance is related to the high specific growth rate in the initial period, probably by early feeding, as the pejerrey larvae have rapid development in hatching with pigmented eyes, mouth and anus opened (SAMPAIO; PIEDRAS, 2005) and the best adaptation and feeding provided, this species being considered zooplanctofagous (PIEDRAS; POUEY, 2005). Another factor to be considered is the energy reserve of the yolk sac, where species with the largest reserves begin exogenous feeding later. The lower initial body weight of $O$. bonariensis may be related to a lower yolk content, once reports of Strüssmann and Takashima (1989) and Phonlor and Vinagre (1990) show that this species had a survival period after hatching under fasting less than $O$. humensis.

The basic assumption for the analysis of the condition factor is that the fish under the best nutritional and health conditions are thicker and therefore heavier for a given length (RICHTER et al., 2000). For the three populations of pejerrey the 
condition factor tended to decrease with increasing days of rearing. Lizama and Takemoto (2000) found that the condition factor is very broad among species, there not being a definite pattern in relation to growth. The species $O$. bonariensis presented higher body weight and condition factor at 180 days, although much less in comparison with the data published by Reartes (1995): $10.10 \mathrm{~g}$ in 141 days; Berasain, Colautti and Velasco (2000): $8.4 \mathrm{~g}$ in 198 days; Velasco, Berasain and Ohashi (2008): 11.28 $\mathrm{g}$ in 196 days. These authors used low stocking density in cement tanks with a surface of $100 \mathrm{~m}^{2}$, where only the replacement of water was held and there was no excessive cleaning management, decreasing the stress factor.

The specific growth rate is a common criterion used for selection in aquaculture breeding programs, where domesticated fish have higher growth rates than wild animals, due to higher rates of food consumption, more efficiency in using food and genetic effects (SACOBIE et al., 2012). The specific growth rate for the body weight tended to decrease throughout the period similar to that found by Velasco, Berasain and Ohashi (2008) in experiment of intensive production of $O$. bonariensis juveniles.

In the period from 90 to 120 days, Humensis and Bonariensis populations showed drastic decrease in specific growth rate for body weight, but the Hybrid population had increased, resulting in higher body weight than the population Humensis at 120 days. This decrease was possibly due to stress (TSUZUKI et al., 2007; PIEDRAS et al., 2009) generated by adjusting animal density at day 90 , where the condition factor decreased from 90 to 120 days in Humensis and Bonariensis populations and increased in the Hybrid ones. According to Gomiero and Braga (2003), the condition factor indicates the degree of fish's well-being against the environment they live in and it must remain constant, regardless of size that the fish might have in a given period.
The coefficient of allometry has an important biological significance, indicating the rate of weight gain compared to the growth in length (FROTA; COSTA; BRAGA, 2004) and can be isometric when the allometric coefficient is equal to three, when negative allometric when allometric coefficient is less than three or positive allometric when the allometric coefficient is higher than three.

Colautti, Lenicov and Berasain (2006) states that the rates of growth between total length and body weight of fish are allometric, ie, these ratios are not constant. The alometric coefficient was higher than three for the three groups, similar to those of Colautti, Lenicov and Berasain (2006) for natural populations of $O$. bonariensis, and different from those found by Becker, Bruschi and Peret (2003). These authors analyzed the three Odontesthes species: Odontesthes bicudo, Odontesthes piquava and Odontesthes ledae, showing isometric growth for juvenile and adult animals, except for adults of O. piquava that showed negative allometric growth. Due to the allometric coefficient of the Hybrid population being lower than the others, the estimated maximum body weight was greater and its estimated total length was lower, showing that Hybrid fish have a more rounded conformation estimated than $O$. bonariensis and $O$. humensis. This study concludes that the growth performance is influenced by the species and $O$. bonariensis showed the best growth performance for 180 days when reared in intensive conditions. Hybrid fish showed intermediate growth and estimates of maximum body weight exceeding the pure species. Based on these results, it would be helpful the selection of breeders and formation of domesticated strains.

\section{Acknowledgments}

The authors are grateful to CNPq and to the PPGZ at the Universidade Federal de Pelotas for financial support. We thank members of the Laboratory of Ichthyology at the Universidade Federal de Pelotas for help in developing the Work. 


\section{References}

BAGENAL, T. Methods for the assessment of fish production in fresh waters. London: Blackwell, 1978. $313 \mathrm{p}$.

BAIGÚN, C. R. M.; COLAUTTI, D. C.; GROSMAN, F. Assessment of condition in pejerrey Odontesthes bonariensis (Atheriniformes: Atherinopsidae) populations: which index works best? Neotropical Ichthyology, Porto Alegre, v. 7, n. 3, p. 439-446, 2009.

BECKER, F. G.; BRUSCHI, W.; PERET, A. C. Age and growth of three Odontesthes species from southern Brazil (Atherinopsidae), with reference to phylogenetic constraints in their life-history. Brazilian Journal of Biology, São Carlos, v. 63, n. 4, p. 567-78, 2003.

BEMVENUTI, M. A. Silversides in South Brazil: morphological and ecological aspects. Biocell, Mendoza, v. 30, n. 1, p. 111-118, 2006.

BERASAIN, G. E.; COLAUTTI, D. C.; VELASCO, C. Culture of the pejerrey, Odontesthes bonariensis, during its first year of life. Revista de Ictiología, Corrientes, v. 8, n. 1-2, p. 1-7, 2000.

COLAUTTI, D. C.; LENICOV, M. R.; BERASAIN, G. E. A standard weight equation to assess the body condition of pejerrey. Biocell, Mendoza, v. 30, n. 1, p. 131-135, 2006.

COLAUTTI, D. C.; SOUZA, J. R. G.; BALBONI, L.; BAIGÚN, C. R. M. Extensive cage culture of pejerrey (Odontesthes bonariensis) in a shallow pampean lake in Argentina. Aquaculture Research, London, v. 41, n. 10, p. 376-384, 2010.

COSTA, M. P. V.; SILVA, R. Z.; SAMPAIO, L. A.; COUSIN, J. C. B. Larval microanatomy of marine silverside Odontesthes argentinensis from Rio Grande do Sul - Brazil. Biociências, Porto Alegre, v. 17, n. 1, p. 91-105, 2009.

DYER, B. S. Systematic revision of the South American silversides (Teleostei, Atheriniformes). Biocell, Mendoza, v. 30, n. 1, p. 69-88, 2006.

FROTA, L. O.; COSTA, P. A. S.; BRAGA, A. C. Lengthweight relationships of marine fishes from the central Brazilian coast. NAGA, Penang, v. 27, n. 1, p. 20-26, 2004.

GJEDREM, T. Genetic variation in quantitative breeding in fish and shellfish traits and selective. Aquaculture, Philadelphia, v. 33, n. 1-4, p. 51-72, 1983.

Genetic improvement for the development of efficient global aquaculture: a personal opinion review. Aquaculture, Philadelphia, v. 344-349, n. 1, p. 12-22, 2012.
GJEDREM, T.; ROBINSON, N.; RYE, M. The importance of selective breeding in aquaculture to meet future demands for animal protein. Aquaculture, Philadelphia, v. 350-353, n. 1, p. 117-129, 2012.

GOMIERO, L. M.; BRAGA, F. M. S. Length-weight relationship and condition factor for Cichla cf. ocellaris and Cichla monoculus (Perciformes, Cichlidae) in Volta Grande Reservoir, Rio Grande - MG/SP. Acta Scientiaru, Maringá, v. 25, n. 1, p. 79-86, 2003.

GREEN, B. W.; RAWLES, S. D. Comparative growth and yield of channel catfish and channel X blue hybrid catfish fed a full or restricted ration. Aquaculture Research, London, v. 41, n. 9, p. 109-119, 2010.

GROSMAN, F. Fundamentals biological, economic and social for proper resource management pejerrey. Buenos Aires: Astyanax, 2002. 132 p.

HULATA, G. Genetic manipulations in aquaculture: a review of stock improvement by classical and modern technologies. Genetica, Amsterdam, v. 111, n. 1-3, p. 155-173, 2001.

LIZAMA, M. A. P.; TAKEMOTO, R. M. Relationship between the growth pattern and different trophic categories: a hypothesis to be tested. Acta Scientiarum, Maringá, v. 22, n. 2, p. 455-463, 2000.

MIRANDA, L. A.; BERASAIN, G. E.; VELASCO, C. A. M.; SHIROJO, Y.; SOMOZA, G. M. Natural spawning and intensive culture of pejerrey Odontesthes bonariensis juveniles. Biocell, Mendoza, v. 30, n. 1, p. 157-162, 2006.

NEWKIRK, G. F. Review of the genetics and the potential for selective breeding of commercially important bivalves. Aquaculture, Philadelphia, v. 19, n. 3, p. 209-228, 1980.

PANG, C. K. Production of marine tilapia hybrid for culture in a coastal fish farm. Singapore Journal of Primary Industries, Singapure, v. 32, n. 1, p. 93-105, 2005.

PHONLOR, G.; VINAGRE, L. Artificial fertilization, incubation, growth and survival larval of Odontesthes humensis (DeBuen, 1953) reared in the laboratory. Brazilian Journal of Biology, São Carlo, v. 50, n. 2, p. 35-343, 1990.

PIEDRAS, S. R. N.; POUEY, J. L. O. F. Feeding pejerrey (Odontesthes bonariensis) fingerlings with natural and artificial diets. Ciência Rural, Santa Maria, v. 34, n. 4, p. 1203-1206, 2004.

Feeding of the silverside (Odontesthes bonariensis, Atherinopsidae) in the Mirim and Mangueira lagoons, Rio Grande do Sul, Brazil. Iheringia, Porto Alegre, v. 95, n. 2, p. 117-120, 2005. 
PIEDRAS, S. R. N.; POUEY, J. L. O. F.; MOTOYAMA, I. S.; MARTINS, G. B. Survival of embryos of pejerrey Odontesthes bonariensis and Odontesthes humensis at different concentration of salinity. Biotemas, Florianópolis, v. 22, n. 3, p. 235-238, 2009.

REARTES, J. L. El pejerrey (Odontesthes bonariensis): métodos de cría y cultivo masivo. Rome: FAO. 1995. 35 p.

RICHTER, H.; LÜCKSTÄDT, C.; FOCKEN, U. L.; BECKER, K. An improved procedure to assess fish condition on the basis of length-weight relationships. Archive of Fishery and Marine Research, Hamburg, v. 48, n. 3, p. 226-235, 2000.

RICKER, W. Growth rates and models. In: HOAR, W.; RANDALL, D.; BRETT, J. (Ed.). Fish physiology: bioenergetics and growth. New York: Academic Press, 1979. $786 \mathrm{p}$.

SACOBIE, C. F. D.; GLEBE, B. D.; BARBEAU, M. A.; LALL, S. P.; BENFEY, T. J. Effect of strain and ploidy on growth performance of Atlantic salmon, Salmo salar, following seawater transfer. Aquaculture, Philadelphia, v. 334-337, n. 1, p. 58-64, 2012.

SAMPAIO, L.; PIEDRAS, S. R. N. Cultivation of the marine pejerrey, Odontesthes argentinensis, and freshwater, Odontesthes bonariensis. In: BALDISSEROTO, B.; GOMES, L. (Ed.). Native species for aquaculture in Brazil. Santa Maria: Ed. Universidade Federal de Santa Maria, 2005. 472 p.

SENANAN, W.; KAPUSCINSKI, A. R.; NA-NAKORN, U.; MILLER, L. M. Genetic impacts of hybrid catfish farming (Clarias macrocephalus X C. gariepinus) on native catfish populations in central Thailand. Aquaculture, Philadelphia, v. 235, n. 1, p. 167-184, 2004.
SOMOZA, G. M.; MIRANDA, L. A.; BERASAIN, G. E.; COLAUTTI, D.; LENICOV, M. R.; STRÜSSMANN, C. A. Historical aspects, current status and prospects of pejerrey aquaculture in South America. Aquaculture Research, London, v. 39, n. 7, p. 784-793, 2008.

STRÜSSMANN, C. A.; TAKASHIMA, F. Histology and morphometry of starved pejerrey Odontesthes bonariensis larvae. Nippon Suisan Gakkaishi, Tokyo, v. 55, n. 2, p. 237-246, 1989.

TAVARES, R. A.; NUNES, M. D.; ALMEIDA, D. B.; SILVA, J. C.; VAZ, B. S.; MOREIRA, C. G. A.; DIONELLO, N. J. L.; PIEDRAS, S. R. N.; MOREIRA, H. L. M. Utilization of microsatellite markers to form families of "pejerrey" Odontesthes bonariensis in a genetic breeding program. Brazilian Journal of Veterinary and Animal Science, Belo Horizonte, v. 63, n. 5, p. 1263-1267, 2011.

TAVE, D. Selective breeding programmes for mediumsized fish farms. Rome: FAO, 1996. $122 \mathrm{p}$.

TSUZUKI, M. Y.; AIKAWA, H.; STRÜSSMANN, C. A.; TAKASHIMA, F. Comparative survival and growth of embryos, larvae, and juveniles of pejerrey Odontesthes bonariensis and $O$. hatcheri at different salinities. Journal of Applied Ichthyology, London, v. 16, n. 1, p. 126-130, 2000.

TSUZUKI, M. Y.; OGAWA, K.; STRÜSSMANN, C. A.; MAITA, M.; TAKASHIMA, F.; MELO, C. M. R. The significance of cortisol on acclimation to salinity in pejerrey Odontesthes bonariensis. Brazilian Journal of Veterinary and Animal Science, Belo Horizonte, v. 59, n. 5, p. 1301-1307, 2007.

VELASCO, C.; BERASAIN, G. E.; OHASHI, M. Intensive production of juvenile pejerrey (Odontesthes bonariensis). Biología Acuática, Buenos Aires, v. 24, n. 1, p. 53-58, 2008. 